\title{
DİYET LİFİ İLE ZENGİNLEŞTİRİLMİŞ GLUTENSİZ KEK HAMURLARININ YÜKSEK GENLİKLİ SALINIMLI KAYMA ANALİZİ (LAOS) İLE REOLOJİK KARAKTERIZZASYONU
}

\author{
Esra Özyiğit ${ }^{1}$ İsmail Eren ${ }^{2}$, Seher Kumcuoğlu ${ }^{1 *}$, Şebnem Tavman ${ }^{1}$ \\ ${ }^{1}$ Ege Üniversitesi, Gıda Mühendisliği Bölümü, İzmir, Türkiye \\ ${ }^{2}$ Manisa Celal Bayar Üniversitesi, Gıda Mühendisliği Bölümü, Manisa, Türkiye
}

Geliş / Received: 07.10.2019; Kabul / Accepted: 07.02.2020; Online bask1 / Published online: 29.03.2020

Özyiğit, E., Eren, İ., Kumcuoğlu, S., Tavman, Ş. (2020). Diyet lifi ile zenginleştirilmiş glutensiz kek hamurlarının yüksek genlikli salınımlı kayma analizi (LAOS) ile reolojik karakterizasyonu. GID A (2020) 45(2) 356-368 doi: 10.15237/gida.GD19131

Özyiğit, E., Eren, I., Kumcuoğlu, S., Tavman, S.. (2020). Large amplitude oscillatory shear (LAOS) analysis of glutenfree cake batters: The effect of dietary fiber enrichment. GID A (2020) 45(2) 356-368 doi: 10.15237/gida.GD19131

\section{ÖZ}

Bu çalısmada, pirinç unu ve karabuğday unu ile hazırlanan glutensiz kek hamurlarına diyet lifi kaynağı olarak portakal lifi (PL) ilavesinin hamurun reolojik özellikleri üzerine olan etkileri Yüksek Genlikli Salınımda Kayma (LAOS) yöntemi kullanılarak incelenmiştir. Çalışma kapsamında glutensiz kek örneklerinin bazı kalite özellikleri de (dokusal özellikleri, özgül hacim) belirlenmiștir. Glutensiz kek formülasyonuna diyet lifi kaynağı olarak portakal lifi farklı oranlarda $(\% 0, \% 4, \% 8, \% 12, \% 16)$ karabuğday unu yerine ilave edilmiştir. Sonuçlar, glutensiz hamurlara diyet lifi ilave edilmesiyle örneklerin elastik $\left(G^{\prime}\right)$ ve viskoz $\left(G^{\prime}\right)$ modülüs değerlerinde artı̧̧ olduğunu göstermiştir. Düşük gerinim değerlerinde örneklerin doğrusal viskoelastik özellik gösterdiği; ancak, uygulanan gerinim genliğinin artmasıyla birlikte reolojik özelliklerin doğrusal olmayan bölgeye giriş yaptı̆̆ belirlenmiştir. Glutensiz kek hamurlarının içerdiği diyet lifi oranının artmasıyla keklerin özgül hacim değerleri artmış $(P<0.05)$, sertlik değerleri azalmıştır $(P<0.05)$.

Anahtar kelimeler: Yüksek genlikli salınımda kayma (LAOS), glutensiz kek hamuru, diyet lifi, portakal lifi

\section{LARGE AMPLITUDE OSCILLATORY SHEAR (LAOS) ANALYSIS OF GLUTEN- FREE CAKE BATTERS: THE EFFECT OF DIETARY FIBER ENRICHMENT}

\begin{abstract}
In this study, the effect of orange fiber (dietary fiber source) addition on gluten free batters from rice flour and buckwheat flour rheological properties was investigated by using LAOS method. The effect of different amount dietary fiber on some quality parameters (textural properties, specific volume) of gluten free cakes were also investigated. Gluten-free cake batters were formulated by replacing buckwheat flour with orange fiber at different levels $(0 \%, 4 \%, 8 \%, 12 \%$ and $16 \%)$. Results showed an increase in storage $\left(G^{\prime}\right)$ and loss $\left(G^{\prime \prime}\right)$ moduli values with the addition of dietary fiber in the gluten free batter. All gluten-free cake batter samples showed linear viscoelastic properties at small strain amplitudes but rheological properties enters the non-linear region by increasing strain amplitude. Increaing the dietary fiber amount caused to increase in specific volume $(P<0.05)$ of gluten free cakes and decrease in hardness value $(P$ $<0.05)$ of cakes.
\end{abstract}

Keywords: Large Amplitude Oscillatory Shear (LAOS), gluten-free batter, dietary fiber, orange fiber

*Yazışmalardan sorumlu yazar/ Corresponding author

$\square$ seher.kumcuoglu@ege.edu.tr,

(c) (+90) 2323113023

司 (+90) 2323114831

Esra Özyiğit; ORCID no: 0000-0003-2579-2828

İsmail Eren; ORCID no: 0000-0001-9724-2580

Seher Kumcuoğlu; ORCID no: 0000-0002-3663-2881

Şebnem Tavman; ORCID no: 0000-0002-6042-7482 


\section{GİRIŞ}

Son yıllarda çölyak hastalığında ve gluten bazlı rahatsızlıkların gözlemlenmesindeki artış glutensiz firnn ürünlerine olan ilginin artmasina neden olmaktadır (Matos ve Rosell, 2011). Çölyak hastalığının tek tedavi yöntemi ise bireyin ömür boyu glutensiz bir diyet uygulamasidır. Ancak glutensiz beslenmenin aşırı kalori, protein ve yağ alımı ile karakterize edilmesi ve kompleks karbonhidrat ve diyet lifi alımını azaltması glutensiz diyet ile ilgili endişelerin devam etmesine neden olmaktadir (Fasano vd., 2003; Thompson vd., 2005).

Glutensiz firın ürünlerinin üretilmesinde glutenin uzaklaştırılması, glutenin yapısal protein olmasından dolayı teknolojik bir zorluk olarak karşımıza çıkmakta; ufalanan doku yapısı, düşük ağız hissi gibi kalite kusurlarına neden olmaktadır (Arendt vd., 2002; Bagley vd., 1998; Sicherer ve Sampson, 2014). Bu nedenle, glutensiz firrn ürünlerinin, gluten içeren firın ürünlerine eşdeğer besin içeriğine ve kalite karakteristiklerine sahip özellikte üretilmesi için tekrar formüle edilmesi gerekmektedir (Gularte vd., 2012).

Diyet lifi, bireylerin ince bağırsağında emilime ve sindirime direnç gösteren; kalın bağırsağında kısmen veya tamamen fermente olabilen bitkilerin yenilebilir kısımlarıdır (Gelroth ve Ranhotra, 2001; Sabanis vd., 2009). Sağlık açısından destekleyici birçok özelliğinin belgelendirilmiş olmasinın yanı sıra (Bazzano vd., 2003; Faivre ve Bonithon-Kopp, 1999; Roehrig, 1988), diyet lifi ilavesi glutensiz firnn ürünlerinin dokusal ve duyusal özelliklerinin geliştirilmesini sağlamaktadır. Diyet liflerinin su tuma kapasiteleri, jel oluşturma yetenekleri, dokulaştırma ve kalınlaştırma etkileri glutensiz hamurların reolojik özelliklerinde ve son ürünün kalitesinde önemli rol oynamaktadır (Gelroth ve Ranhotra, 2001; Thebaudin vd., 1997).

Glutensiz hamurların reolojik karakterizasyonun belirlenmesi için glutensiz pirinç keki (Turabi vd., 2008; Tsatsaragkou vd., 2015), glutensiz ekmek (Demirkesen vd., 2010; Torbica vd., 2012), glutensiz muffinler (Matos vd., 2014) ve kekler (Lebesi ve Tzia, 2011) üzerine çeşitli çalışmalar bulunmaktadır. Gerçekleştirilen bu çalışmalar düşük genlikli salınımda kayma (SAOS) analizleri üzerine yoğunlaşmakta ve örneklerin doğrusal bölgedeki başlangıç gerilim ve gerinim tepkilerini tanımlamaktadır (Joyner ve Meldrum, 2016). Ancak, gidalarda gerçekleştirilen birçok proses ise doğrusal olmayan özellik göstermektedir (Ptaszek, 2015).

Viskoelastik özelliklerin karakterize edilmesinde elastik modül ve viskoz modül dikkate alınmaktadır. Doğrusal bölgede uygulanan gerinim genliği yeterince küçük olduğu için viskoelastik modüller uygulanan gerinim genliğinden bağımsız ve buna bağlı olarak elde edilen salınımla stres tepkileri ise sinüsodial formdadır. Gerinim genliğinin artması sonucunda SAOS'un ötesinde doğrusal olmayan bölge oluşmaktadır. Doğrusal olmayan bölgede elastik ve viskoz modüller, gerinim genliğinin bir fonksiyonu olmakta ve elde edilen stres dalgaları bozularak sinüsodial formdan sapmaktadır (Hyun vd., 2011). Bu yüzden gidaların temel reolojik Özelliklerinin tanımlanmasında Yüksek Genlikli Salınımda Kayma (LAOS) analizlerine olan ilgi artmaktadir.

LAOS analizi ile gida köpüklerinin (Ptaszek, 2015), sert buğday unlu hamurun (Yazar vd., 2017), süspansiyonların, emülsiyonların ve elastik ağların (Duvarci vd., 2017) reolojik karakterizasyonu üzerine gerçekleştirilen başarllı çalışmalar bulunmaktadır. Ancak, diyet lifi ile zenginleştirilmiş glutensiz firrn ürünleri daha az dikkat çekmiştir. Çalışma kapsamında diyet lifi ile zenginleştirilmiş glutensiz kek formülasyonları geliştirilerek, elde edilen ürünlerin reolojik özelliklerinin LAOS tekniği kullanılarak belirlenmesi amaçlanmıştır.

\section{MATERYAL VE YÖNTEM \\ Materyal}

Glutensiz keklerin üretiminde pirinç unu (Kenton, Ankara), karabuğday unu (Değirmen, İzmir), portakal lifi (Herba Food, Almanya), süt (Pınat Süt Mamülleri Sanayi A.Ş., İzmir) pastörize tüm yumurta (Ipay A.,Ş., Türkiye), şeker, pastacilık yağı (Felda Iffco Gıda San. ve Tic. A.Ş., Izmir), vanilya, kabartma tozu (Dr-Oetker Gida San. ve Tic. A.Ş., İzmir) ve ksantan gam (SigmaAldrich, St. Louis, USA) kullanılmıştır. 
Karabuğday tohumları çekiçli değirmen (Armfield, UK) ile öğütülerek karabuğday unu $(250 \mu \mathrm{m})$ elde edilmiştir.

\section{Glutensiz Kek Örneklerinin Üretimi}

Diyet lifi olarak portakal lifi farklı oranlarda (\%4, $8,12,16)$ karabuğday unu ile yer değiştirecek şekilde formülasyona ilave edilmiştir. Diyet lifi ilave edilmeden üretilen glutensiz kek örneği "kontrol" olarak adlandırılmışır. Çizelge 1'de glutensiz kek üretiminde kullanılan formülasyon $100 \mathrm{~g}$ un karışımı için verilmiştir.

Çizelge 1. Farklı oranlarda diyet lifi içeren glutensiz kek formülasyonları (g) Table 1. Gluten-free cake formulation (g)

\begin{tabular}{lccccc}
\hline \multirow{2}{*}{$\begin{array}{l}\text { Bileşen (g) } \\
\text { Ingredients (g) }\end{array}$} & \multicolumn{5}{c}{$\begin{array}{c}\text { Portakal lifi (\%) } \\
\text { (Orange fiber \%) }\end{array}$} \\
\cline { 2 - 6 } & $\begin{array}{l}\text { Kontrol } \\
\text { (Control) }\end{array}$ & $\% 4$ & $\% 8$ & $\% 12$ & $\% 16$ \\
\hline Pirinç unu (Rice flour) & 80 & 80 & 80 & 80 & 80 \\
Karabuğday (Buckwheat) & 20 & 16 & 12 & 8 & 4 \\
Lif kaynağ1 (Dietary fiber) & 0 & 4 & 8 & 12 & 16 \\
Yumurta (Egg) & 80 & 80 & 80 & 80 & 80 \\
Şeker (Sugar) & 80 & 80 & 80 & 80 & 80 \\
Pastacilik yağ1 (Shortening) & 25 & 25 & 25 & 25 & 25 \\
Süt (Milk) & 120 & 120 & 120 & 120 & 120 \\
Kabartma tozu (Baking powder) & 6 & 6 & 6 & 6 & 6 \\
Vanilya (Vanillin) & 1 & 1 & 1 & 1 & 1 \\
Gam (Gum) & 0.5 & 0.5 & 0.5 & 0.5 & 0.5 \\
\hline
\end{tabular}

Glutensiz kek hamurları Kitchen Aid Mikser (St. Joseph, Mich., USA) kullanılarak elde edilmiştir. Glutensiz kek üretimi amaciyla yumurta mikser yardımıla yüksek devirde 4 dakika boyunca karıştırılmış ve şeker ilave edilerek 3 dakika daha yüksek devirde karıştırma işlemi gerçekleştirilmiştir. Daha sonra, pastacılık yağı ve süt ilave edilerek orta hızda 2 dakika daha karıştırılmıştır. Diğer tüm kuru bileşenlerin ilave edilip, 1 dakika daha düşük hızda karıştırma işlemi gerçekleştirilmesiyle glutensiz kek hamuru elde edilmiştir. 80 g'lık kek hamurları silikon kek kalıplarında konvensiyonel firında (Vestel, Türkiye), $180^{\circ} \mathrm{C}$ 'de alt ve üst 1sitma modülünde 35 dakika boyunca pişirilmiştir. Pişirilen kekler analizlerde kullanilmak üzere 1 saat oda sıcaklığında bekletilerek, soğuması sağlanmıştır.

\section{Toz Ürünlerde Gerçekleştirilen Analizler Çözünür ve çözünmez diyet lifi analizi}

Portakal lifi, karabuğday unu ve pirinç ununa ait çözünür ve çözünmez diyet lifi içeriği $\mathrm{AOAC}$ (1998) Metot: 991.43’e göre belirlenmiştir.

\section{Su tutma özelliklerinin belirlenmesi}

Glutensiz kek üretiminde kullanılan toz ürünlerin ve un karışımlarının su absorplama indeksi (WAI) ve suda çözünürlük indeksi (WSI) değerleri, Choi vd. (2012)'de verilen yöntem modifiye edilerek belirlenmiştir. Yapılan modifikasyon ile analiz sonucunda elde edilen üst faz $105^{\circ} \mathrm{C}$ 'deki etüvde 1 gece yerine 6 saat bekletilmiştir.

\section{Glutensiz Kek Hamurlarında Gerçekleştirilen Analizler}

\section{Reolojik özellikler}

Kek hamurlarında reolojik özelliklerin belirlenmesi amaciyla TA DHR3 (TA Instruments Inc., New Cattle, DE, USA) reometre kullanılmıştır. Hazırlanan hamur örnekleri bekletilmeden analiz edilmişlerdir. Analizler $25 \pm 0.1^{\circ} \mathrm{C}$ 'de, plakalar arası boşluk $1 \mathrm{~mm}$ olacak şekilde $40 \mathrm{~mm}$ çapl paralel plaka kullanılarak gerçekleştirilmiştir. LAOS testi 10 $\mathrm{rad} / \mathrm{s}$ sabit frekansinda, \%0.01- 300 gerinim aralığında ve 40 farklı döngü elde edilecek şekilde gerçekleştirilmiştir. Test sonucunda elde edilen 
Lissajous eğrileri ve Chebysev katsayları değerlendirilerek örnek davranışı hakkında bilgi sahibi olunmuştur. Ölçümler 2 paralel olacak şekilde gerçekleştirilmiştir.

\section{Yoğunluk}

Kek hamurlarında yoğunluk ölçümü Elcometer (Elcometer, Manchester, UK) piknometre kullanılarak gerçekleştirilmiştir.

\section{Glutensiz Kek Örneklerinde Gerçekleştirilen Analizler Özgül hacim}

AACC (2000) Metot $72-10$ 'da belirtilen kolza tohumu ile yer değiştirme prensibine göre kek örneklerinin özgül hacim değerleri belirlenmiştir.

\section{Doku Profil Analizi}

Doku profili analizi, TA.XT Express doku analiz cihaz1 (Stable Microsystems, Surrey, UK) ile Gómez vd. (2007)'de belirtilen yöntemin modifiye edilmesiyle gerçekleştirilmiştir. Pişirilen kek örnekleri analiz öncesinde yirmi dört saat dinlendirilmiş ve sonrasında kesme cihazı yardımıla 40x40x15 mm boyutlarında dilimlenmiştir. Doku profili analizi $25 \mathrm{~mm}$ çaplı alüminyum silindirik prob ve 10 N'luk yük hücresi kullanılarak gerçekleştirilmiştir. Test sırasında kek örneği orjinal kalınlığının \%50'sine sıkıştırılmış ve $2 \mathrm{~mm} / \mathrm{s}$ test hızında ölçümler arası 30 saniye bekletilerek analiz yapılmıştır. Ölçümler 10 paralel olacak şekilde gerçekleştirilmiştir (Gomez vd., 2007).

\section{İstatistiksel Analiz}

Elde edilen deneysel veriler arasinda önemli fark $(P<0.05)$ olup olmadığını belirlemek amacıyla IBM SPSS 20 programı kullanılarak tek yönlü varyans analizi (ANOVA) ile istatistiksel analiz gerçekleştirilmiştir. Önemli düzeyde fark olması durumunda ise karşılaşturma için Duncan çoklu karşılaştırma testi kullanılmıştır.

\section{SONUÇ VE TARTIŞMA \\ Toz Ürünlerin Özellikleri}

\section{Çözünür ve çözünmez diyet lifi}

Glutensiz kek üretiminde diyet lifi kaynağı olarak kullanılan hazır portakal lifi, karabuğday unu ve pirinç ununa ait çözünür ve çözünmez diyet lifi içeriği belirlenmiş olup, portakal lifinin \%21.58 çözünür ve \%43.34 çözünmez diyet lifi içeriğiyle \%64.93 toplam diyet lifi içerdiği saptanmıştır. Toplam diyet lifi içeriği \%50'nin üzerinde olan diyet lifi kaynakları, zengin diyet lifi içeriğine sahip ürünler olarak kabul edilmektedir (Larrauri, 1999). de Moraes Crizel vd. (2013) çalışmalarında üretilen portakal liflerine ait toplam diyet lifi içeriklerini \%63.6 ve \%63.7 olarak belirtmekte ve sonuçlar çalışmamız ile paralellik göstermektedir. Karabuğday ununda \%2.25 çözünür ve \%14.02 çözünmez olmak üzere toplam diyet lifi miktarı \%16.27 olarak belirlenmiștir. Geleneksel ve tatar karabuğday unlarının kompozisyonlarının belirlendiği bir çalışmada toplam diyet lifi içerikleri $\% 6.77$ ve $\% 6.29$ olarak belirtilmektedir (Bonafaccia vd., 2003). Steadman vd. (2001) rengi koyu karabuğday ununa ait toplam diyet lifi içeriğini \%8.5 olarak belirtmiştir. Bu durum karabuğday tohumlarının yetiştirme koşullarında ve ögütme yöntemlerindeki farkllıklardan dolayı diyet lifi içeriği değişkenlik göstermektedir (Bonafaccia vd., 2003). Pirinç ununun içerdiği diyet lifi miktarı ise \%2.43'u çözünür ve \%5.52'si çözünmez olmak üzere toplam diyet lifi içeriği \%7.91 olarak belirlenmiştir.

\section{Su tutma özellikleri}

Gida sistemlerinde su absorplama indeksi (WAI) unların suyu absorblama ve şişme özelliklerini ifade etmektedir. Bu sayede ürünün kıvam ve yapısı hakkında bilgi sahibi olunmakta ve arzu edilen yapıda ürün elde edilmesine katk1 sağlanmaktadır. Suda çözünürlük indeksi (WSI) ise nişasta degradasyonunu belirtmek için kullanılır. Böylece ürüne aşırı miktarda su eklenmesi durumunda serbest polisakkaritlerin ve polisakkaritlerden salınan serbest granüllerin miktarı belirlenmektedir (Osundahunsi vd., 2003; Choi vd., 2012).

Yapılan analiz sonucunda WAI değerleri, pirinç unu için $2.99 \pm 0.06 \mathrm{~g} / \mathrm{g}$, karabuğday unu için $2.22 \pm 0.02 \mathrm{~g} / \mathrm{g}$ ve portakal lifi için $7.28 \pm 0.46 \mathrm{~g} / \mathrm{g}$ olarak bulunmuştur. WSI değerleri ise pirinç unu için \%2.19 \pm 0.14 , karabuğday unu için $\% 6.83 \pm 0.08$ ve portakal lifi için $\% 7.71 \pm 0.06$ olarak hesaplanmıştır (Çizelge 2). Portakal lifi su absorplama indeksinin yüksek olmasından dolayı 
kaloriyi azaltıcı etki gösteren ve gıdanın viskozitesi ile yapısını değiştirebilen fonksiyonel bir bileşendir. Yapılan bir çalışmada Valencia Late türüne ait portakal liflerinin WAI değeri 7.30 olarak bulunmuştur (Grigelmo-Miguel ve Belloso, 1999). de Moraes Crizel vd. (2013) çalışmalarında iki farklı portakal türüne ait su tutma kapasitelerini 8.71 ve 9.63 olarak bulmuştur. Lario vd. (2004) lifin partikül büyüklüğünün artmasıyla su tutma kapasitelerinin de arttığını belirtmiştir.
Toz karışımların su absorplama indeks değerlerinin 3.53 ile 5.04 değerleri arasında değişiklik gösterdiği ve diyet lifi içeriğinin artmasiyla su absorplama indeksinde arţş olduğu saptanmıştır. Aynı şekilde, un karışımlarında portakal lifi içeriğinin artması ve karabuğday unu miktarının azalmasıyla suda çözünürlük indekslerinin 3.54 ile 5.07 arasında artış gösterdiği görülmektedir (Çizelge 2). Bu durum portakal lifinin karabuğday ununa oranla suda çözünürlüğ̈unün ve su absorplama değerinin daha fazla olmasından kaynaklanmaktadır.

Çizelge 2. Farklı oranlarda diyet lifi içeren un karışımlarının su tutma özellikleri Table 2. Water retention properties of flour blends for different dietary fiber amounts

\begin{tabular}{lcc}
\hline Örnek (Sample) & WAI $(\mathrm{g} / \mathrm{g})$ & WSI $(\%)$ \\
\hline Kontrol (Control) & $2.68 \pm 0.009^{\mathrm{a}}$ & $3.54 \pm 0.005^{\mathrm{a}}$ \\
$\% 4 \mathrm{DL}(4 \% D F)$ & $2.98 \pm 0.01^{\mathrm{ab}}$ & $3.89 \pm 0.26^{\mathrm{a}}$ \\
$\% 8 \mathrm{DL}(8 \% D F)$ & $3.08 \pm 0.09^{\mathrm{b}}$ & $4.69 \pm 0.07^{\mathrm{b}}$ \\
$\% 12 \mathrm{DL}(12 \% D F)$ & $3.54 \pm 0.004^{\mathrm{c}}$ & $4.76 \pm 0.22^{\mathrm{b}}$ \\
$\% 16 \mathrm{DL}(16 \% D F)$ & $3.69 \pm 0.26^{\mathrm{c}}$ & $5.07 \pm 0.04 \mathrm{~b}$ \\
\hline
\end{tabular}

Aynı sütundaki ortalamalar arasında farklı harfli değerler arasında istatistiksel olarak anlamlı fark bulunmaktadır $(P<0.05)$.

Different letters in the same column $(a, b, c, d)$ indicate significant differences between means $(P<0.05)$.

\section{Glutensiz Kek Hamurlarının Özellikleri Reolojik özellikler \\ Doğrusal ve doğrusal olmayan bölgelerin belirlenmesi}

Örneklerin doğrusal bölgede stres dalgaları sinüsodial formdayken, doğrusal olmayan bölgede sinüsodial dalgalarda sapmalar meydana gelmektedir. Salınım genliği (oscillation amplitude) analizi sonucunda elde edilen, örneklere ait elastik ve viskoz modül değerleri Şekil 1'de gösterilmektedir.

Glutensiz hamur örneklerinin davranısı belli bir gerinim değerinden sonra değissiklik göstermektedir. Genel olarak \%1 gerinim değerinden sonra tüm örneklerde elastik $\left(G^{\prime}\right)$ ve viskoz $\left(G^{\prime \prime}\right)$ modül davranışı değişmekte ve doğrusal olmayan rejime geçiş yapılmaktadır.

Tüm glutensiz hamur örneklerinin elastik modül $\left(G^{\prime}\right)$ değerleri viskoz modül $\left(G^{\prime \prime}\right)$ değerlerinden daha yüksektir ve hamurun yapisinda elastik karakter baskın olmaktadır. Glutensiz kek formülasyonundaki diyet lifi oranı arttıkça elde edilen elastik ve viskoz modül değerleri de artış göstermektedir. Diyet lifi ile zenginleştirilmiş hamurların $G^{\prime}$ değerleri 0-2000 $\mathrm{Pa}$ aralı̆̆ında, $G^{\prime \prime}$ değerleri ise $0-800 \mathrm{~Pa}$ aralı̆̆ında değişiklik göstermekte, diyet lifi ilavesi kontrol grubu ile kiyaslandığında $G^{\prime}$ ve $G^{\prime \prime}$ değerleri üzerinde oldukça etkili olmuştur. Matos vd. (2014) yaptıkları çalışmada glutensiz muffin hamur formülasyonunda kullanilan protein oranının artmasıyla elastik ve viskoz modülüs değerlerinin arttı̆̆ını belirtmişlerdir. Shevkani vd. (2015) ise protein izolatı içeren ve içermeyen pirinç keki hamurlannda elastik modül değerlerinin, viskoz modül değerlerinden daha yüksek olduğu sonucuna varmışlardır.

\section{Genel Lissajous Eğrilerinin Karşılaştırılması}

Doğrusal olmayan bölgede glutensiz kek hamurlarının reolojik özellikleri gerinim genliğinin bir fonksiyonu olarak ifade edilmektedir. LAOS analizi sonucunda farklı gerinim genliklerinde (0.01-300\%), $10 \mathrm{rad} / \mathrm{s}$ açısal hız ile elde edilen 23 döngünün değerlendirilmesiyle Şekil 2'deki Lissajous eğrileri elde edilmiştir. Bu şekilde elastik 
ve viskoz modüllerin stres fonksiyonlarının analitik olarak değerlendirilmesinden önce doğrusal olmayan özelliklerindeki farkliliklar görsel olarak incelenebilmektedir. Aynı zamanda gerinim ile sertleşen/yumuşayan ve kayma ile incelen/kalınlaşan davranışlanının doğrusal olmayan bölgede daha iyi anlaşılmasını sağlamaktadır.

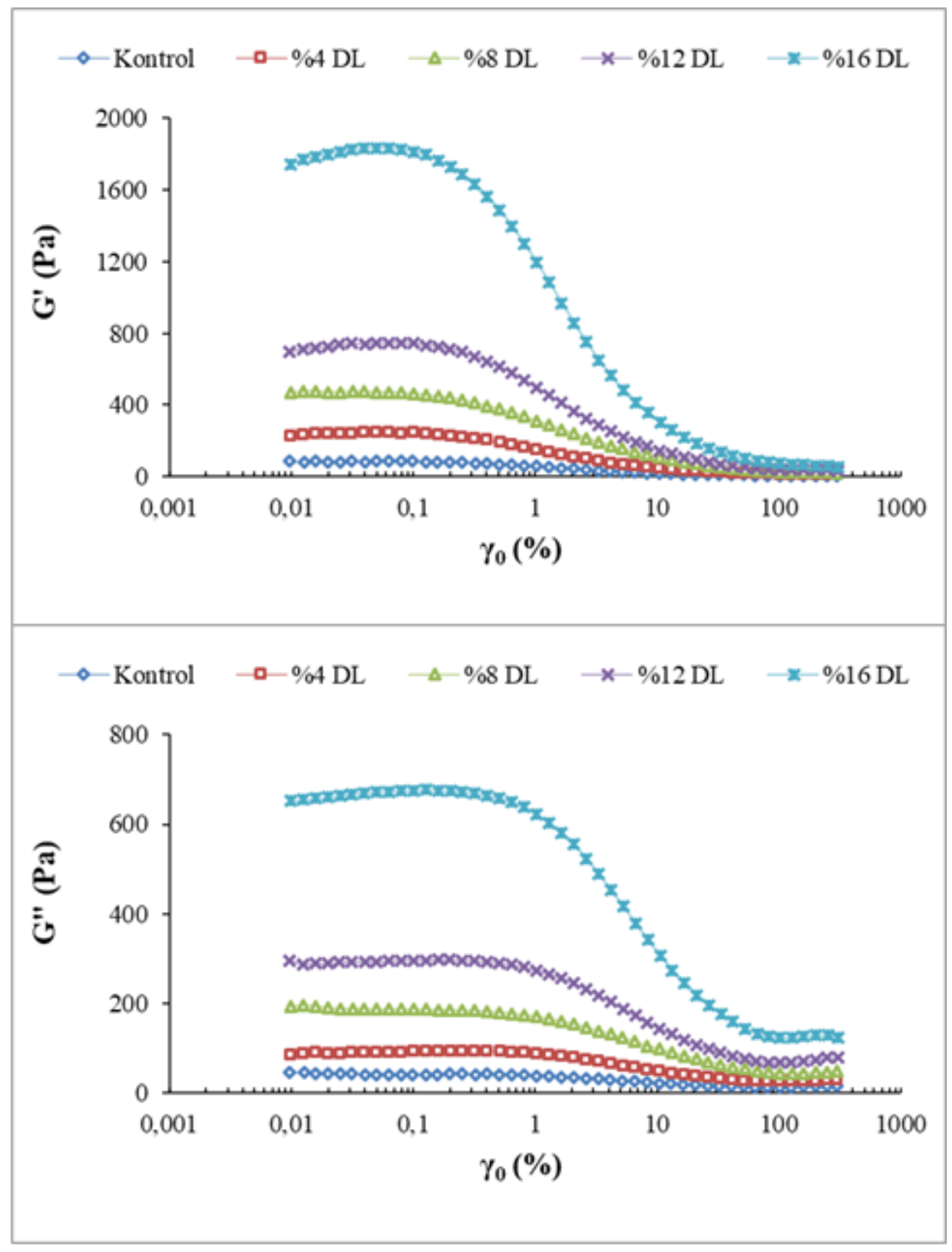

Şekil 1. Farklı oranlarda diyet lifi içeren örneklere ait salınım genliği analizi sonucunda elde edilen grafikler $(10 \mathrm{rad} / \mathrm{s})$

Fig. 1. Oscillation amplitude analysis results of gluten-free cake batters for different dietary fiber concentraions at 10 $\mathrm{rad} / \mathrm{s}$. 

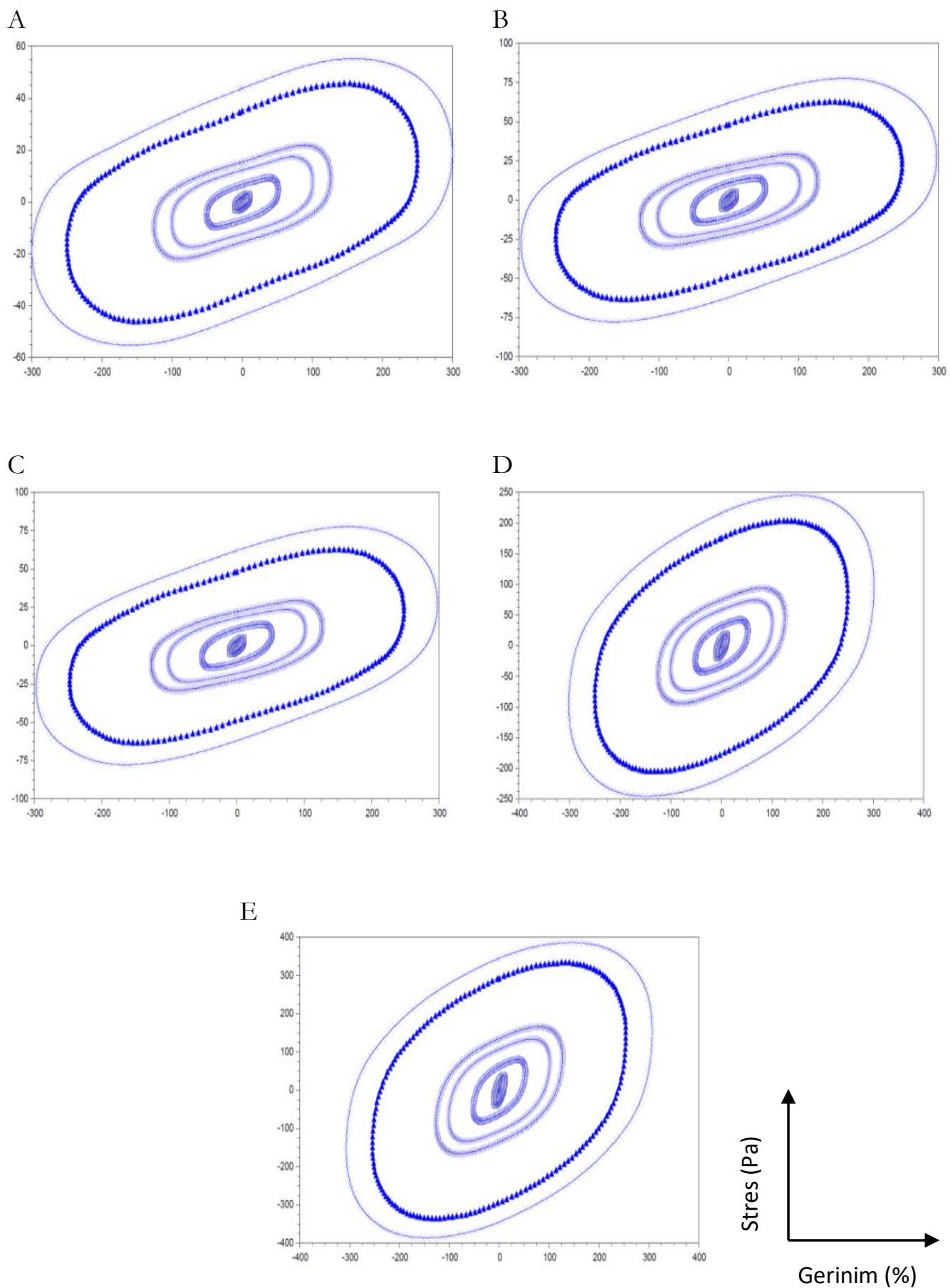

Şekil 2. Glutensiz kek hamurlarına ait \%0.01-300 gerinim aralığındaki Lissajous eğrileri (kontrol:A, \%4 DL:B, \%8 DL:C, \%12 DL:D, \%16 DL:E).

Fig. 2. The Lissajous curves for gluten-free cake batters at different strains between 0.01-300\% (Control: A, \%4 DF:B, \%8 DF:C, \%12 DF:D, \%16 DF:E) 
Elde edilen Lissajous eğrilerindeki farkll1ıklar örneklerin viskoelastik davranışlarındaki değişimleri ifade etmektedir. Glutensiz kek örneklerinin içerdiği diyet lifi miktarı arttıkça daha yüksek stres değerleri elde edilmekte ve en yüksek stres değerine sahip örnek \%16 diyet lifi içeren kek örneği olmaktadır. Lissajous eğrilerinin ortasındaki küçük döngüler doğrusal viskoelastik bölgeyi ifade etmektedir. Kek hamurlarının diyet lifi ile artan oranlarda zenginleştirilmesi döngüleri ve saat yönüne doğru olan dönüşü etkilemektedir (Ng vd., 2011; Duvarci vd., 2017).

\section{Chebysev Harmoniklerinin Değerlendirilmesi}

Geometrik olarak bozulmayı ifade eden Lissajous eğrileri örneklerin reolojik özelliklerinin analizinin temelini oluşturmakta; Chebyshev katsayılarının incelenmesi ile örnek davranışı hakkında daha kapsamlı bilgi elde edilmektedir. Analiz sonucunda elde edilen Chebyshev katsayllarının değerleri harmoniğin artmasıla birlikte hızlı bir şekilde düşmekte ve ortadan kaybolmaktadır. Bu yüzden Chebysev katsayılarının birinci Chebyshev katsayısı ile normalleştirilerek kullanılması daha uygundur (Şekil 3).

Farklı oranlarda diyet lifi içeren örneklere ait normalleştirilmiş 3.Chebysev harmonikleri incelendiğinde; tüm örneklerin \%-0.01-0 gerinim değerleri arasında doğrusal elastik ve viskoz davranış gösterdiği görülmektedir. Diyet lifi içermeyen ve \%4 oranında diyet lifi içeren örneklerin yaklaşık \%60 gerinim $\left(\gamma_{0}\right)$ değerine kadar pozitif değerde olduğu ve gerinim ile sertleşen özellik gösterdiği görülmektedir. Bu değerden sonra elde edilen değerler sıfırdan küçük olmakta ve gerinim ile yumuşayan özellik gösterdiği anlaşılmaktadır. Diyet lifi miktarı arttıkça örneklere ait $e_{3} / e_{1}$ değerlerinin pozitif olduğu gerinim aralı̆̆1 genişlemektedir. Böylece diyet lifi miktarının artmasıyla birlikte örneklerin gerinim ile sertleşen özellik gösterdiği aralık artmakta; gerinim ile yumuşama özelliği görülen aralık ise azalmaktadır. Genel davranış olarak örneklerin $v_{3} / v_{1}$ değerleri $\% 0$ gerinim değerinden sonra sıfırdan küçük olmaktadır. Her bir örnek için farklı olmak üzere belli bir gerinim değerine ulaştıktan sonra ise artış görülmektedir. Glutensiz keklerin $v_{3} / v_{1}$ değerleri \%0-300 gerinim değerleri arasında sıfırdan küçük olduğu için kayma ile incelen özellik göstermektedir.

\section{Yoğunluk}

Farklı oranlarda diyet lifi kullanilmasiyla elde edilen hamurların yoğunluk değerleri 1.1-1.05 arasında değişiklik göstermekte olup, en yüksek yoğunluk değeri diyet lifi içermeyen örneğe aittir (Çizelge 3).

Çizelge 3. Farklı oranlarda diyet lifi içeren örneklere ait yoğunluk değerleri Table 3. Density of gluten-free cake batters

\begin{tabular}{lc}
\hline Örnek & Yoğunluk $(\mathrm{g} / \mathrm{ml})$ \\
(Sample) & (Density g/ml)) \\
\hline Kontrol (Control) & $1.103 \pm 0.42^{\mathrm{b}}$ \\
$\%$ 4 DL (4\% DF) & $1.052 \pm 0.001^{\mathrm{a}}$ \\
$\%$ 8 DL (8\% DF) & $1.055 \pm 0.004^{\mathrm{a}}$ \\
$\% 12 \mathrm{DL}(12 \% \mathrm{DF})$ & $1.052 \pm 0.000^{\mathrm{a}}$ \\
$\% 16 \mathrm{DL}(16 \% \mathrm{DF})$ & $1.058 \pm 0.001^{\mathrm{a}}$ \\
\hline
\end{tabular}

Aynı sütunda bulunan değerler arasında farklı harf içeren örnekler arasında istatistiksel olarak anlamlı fark bulunmaktadır $(P<0.05)$.

Different letters in the same column $(a, b, c, d)$ indicate significant differences between means $(P<0.05)$.

Hamurların yoğunluk değerleri son ürünün özgül hacmiyle doğrudan ilişkili olmakta; hamur içerisinde tutulan hava miktarı arttıkça yoğunluk değeri düşerek hacmi yüksek ürün elde edilmektedir. Çalışmada kullanılan portakal lifi, karıştırma sırasında tutulan hava miktarının artmasını sağlayarak hamur yoğunluğunun azalmasını sağlamaktadır. Diyet lifi içeren örneklere ait yoğunluk değerlerinin kontrol grubundan düşük olmasından dolayı kek örneklerinin hacimlerinde artış beklenmektedir. 




Şekil 3. Glutensiz kek örneklerine ait gerinim genliğine karşıllık $\left(\gamma_{0}=\% 50\right)$ normalize edilmiş Chebyshev değerleri $\left(e_{3} / e_{1}\right.$ ve $\left.v_{3} / v_{1}\right)$

Fig. 3. Normalized Chebyshev coefficients ( $e_{3} / e_{1}$ and $\left.v_{3} / v_{1}\right)$ of gluten free cake batters in function of strain amplitude at $\gamma_{0}=50 \%$.

\section{Glutensiz Kek Örneklerinin Özellikleri Özgül hacim}

Glutensiz kek örneklerine değişen miktarlarda portakal lifi ilave edilmesi sonucunda özgül hacim değerleri $1.58 \mathrm{~cm}^{3} / \mathrm{g}$ ile $1.79 \mathrm{~cm}^{3} / \mathrm{g}$ arasında değişiklik göstermekte olup; elde edilen sonuçlar Çizelge 4'te verilmektedir. Genel davranış olarak glutensiz kek örneklerine diyet lifi ilavesinin özgül hacim değerlerini arttırdığ1 gözlemlenmiştir. Ancak \%12 diyet lifi içeren kek örneklerinin özgül hacminde bir düşüş olmuştur. \% 12 diyet lifi içeren kek örneklerinin özgül hacimlerindeki düşüşün, su tutma kapasitesi gibi farklı karakteristik özelliklere sahip olan portakal lifi ile karabuğday ununun konsantrasyonlarından kaynaklanabileceği düşünülmektedir.

Yapılan bir çalışmada kek örneklerine diyet lifi kaynağ1 olarak karpuz ve kavun kabuklar1 eklendiğinde, özgül hacim değerlerinin 1.84 ile 2.56 arasında değiştiği ve diyet lifi miktarının artmasıyla özgül hacim değerinin arttı̆̆ belirtilmiştir (Al-Sayed ve Ahmed, 2013). Lebesi ve Tzia (2011) buğday, mısır, arpa ve yulaftan elde 
edilen diyet liflerinin ve tahıl kepeğinin kek özellikleri üzerindeki etkilerini inceledikleri çalışmalarında kek örneklerine diyet lifi ilavesinin özgül hacim değerlerini arttırdığını belirtmişlerdir.

Çizelge 4. Farklı oranlarda diyet lifi içeren örneklerin özgül hacim değerleri Table 4. Specific volume of gluten-free cakes

\begin{tabular}{|c|c|}
\hline $\begin{array}{l}\text { Örnek } \\
\text { (Sample) }\end{array}$ & $\begin{array}{l}\text { Özgül hacim }\left(\mathrm{cm}^{3} / \mathrm{g}\right) \\
\left.\text { (Specific volume }\left(\mathrm{cm}^{3} / \mathrm{g}\right)\right)\end{array}$ \\
\hline Kontrol (Control) & $1.58 \pm 0.04^{a}$ \\
\hline$\% 4 \mathrm{DL}(4 \% D F)$ & $1.65 \pm 0.1^{\mathrm{ab}}$ \\
\hline$\% 8 \mathrm{DL}(8 \% \mathrm{DF})$ & $1.79 \pm 0.05^{c}$ \\
\hline$\% 12 \mathrm{DL}(12 \% \mathrm{DF})$ & $1.73 \pm 0.06^{b c}$ \\
\hline$\% 16 \mathrm{DL}(16 \% \mathrm{DF})$ & $1.78 \pm 0.034 \mathrm{c}$ \\
\hline
\end{tabular}

Aynı sütunda bulunan değerler arasında farklı harf içeren örnekler arasında istatistiksel olarak anlamlı fark bulunmaktadır $(P<0.05)$.

Different letters in the same column $(a, b, c, d)$ indicate significant differences between means $(P<0.05)$.

Pişirilen kek örneklerinin son hacmi ve dokusal özellikleri hamur içerisinde tutulan hava miktarı ile doğrudan ilişsilidir. Karıştırma sırasında hamur içerisinde tutulan hava miktarının yeterli olabilmesi için hamurun uygun yoğunlukta ve viskozite değerinde olması gerekmektedir. Düşük kıvama sahip hamurlarda karıştırma ve pişirme sırasinda hava kabarcikları korunamamakta ve düşük hacimli kek elde edilmektedir. Aynı zamanda, hamurun kivaminin artmasiyla da hamurdaki genleşme miktarı kısıtlanmaktadır
(Gomez vd., 2007). Singh vd. (1995)'a göre kek hacminin ve özgül hacim değerlerinin diyet lifi konsantrasyonunun artmasıyla artsş göstermektedir.

\section{Dokusal Özellikler}

Glutensiz kek örneklerine diyet lifi ilavesinin dokusal özellikleri üzerine etkisi ve elde edilen sertlik (hardness), esneklik (springiness), yapışkanlık (cohesiveness) ve elastikiyet (resilience) değerleri Çizelge 5’te verilmiştir.

Çizelge 5. Glutensiz kek örneklerine ait doku profili analizi değerleri

Table 5. Texture profile analysis results of gluten-free cakes

\begin{tabular}{lcccc}
\hline $\begin{array}{l}\text { Örnek } \\
\text { (Sample) }\end{array}$ & $\begin{array}{c}\text { Sertlik } \\
\text { (Hardness, } N)\end{array}$ & $\begin{array}{c}\text { Esneklik } \\
\text { (Springiness) }\end{array}$ & $\begin{array}{c}\text { Yap1şkanllk } \\
\text { (Cobesiveness) }\end{array}$ & $\begin{array}{c}\text { Elastikiyet } \\
\text { (Resilience) }\end{array}$ \\
\hline Kontrol (Control) & $13.2 \pm 1.60^{\mathrm{a}}$ & $0.95 \pm 0.02^{\mathrm{a}}$ & $0.70 \pm 0.27^{\mathrm{a}}$ & $0.33 \pm 0.01^{\mathrm{ab}}$ \\
$\%$ 4 DL (4\% DF) & $11.85 \pm 1.43^{\mathrm{b}}$ & $0.96 \pm 0.01^{\mathrm{a}}$ & $0.70 \pm 0.02^{\mathrm{a}}$ & $0.32 \pm 0.09^{\mathrm{b}}$ \\
$\% 8 \mathrm{DL}(8 \% D F)$ & $10.12 \pm 0.86^{\mathrm{c}}$ & $0.99 \pm 0.14^{\mathrm{a}}$ & $0.73 \pm 0.02^{\mathrm{b}}$ & $0.34 \pm 0.01^{\mathrm{a}}$ \\
$\% 12 \mathrm{DL}(12 \% D F)$ & $9.43 \pm 1.22^{\mathrm{c}}$ & $0.97 \pm 0.08^{\mathrm{a}}$ & $0.71 \pm 0.03^{\mathrm{a}}$ & $0.32 \pm 0.01^{\mathrm{b}}$ \\
$\% 16 \mathrm{DL}(16 \% D F)$ & $9.39 \pm 0.69^{\mathrm{c}}$ & $0.93 \pm 0.021^{\mathrm{a}}$ & $0.69 \pm 0.01^{\mathrm{a}}$ & $0.31 \pm 0.01^{\mathrm{c}}$ \\
\hline
\end{tabular}

Aynı sütunda bulunan değerler arasında farklı harf içeren örnekler arasında istatistiksel olarak anlamlı fark bulunmaktadir $(P<0.05)$.

Different letters in the same column $(a, b, c, d)$ indicate significant differences between means $(P<0.05)$.

Karabuğday unu miktarı azaltılarak ilave edilen diyet lifi oranının keklerin dokusal özelliklerini etkilediği görülmektedir $(P<0.05)$. Glutensiz kek örneklerinin sertlik değerleri 13.2-9.39 N arasında değişim göstermekte ve diyet lifi miktarının artmasiyla azalmaktadır. Lebesi ve Tzia (2011), buğday unu miktarından azaltılarak ilave edilen diyet lifi (buğday, yulaf, arpa, mısır) miktarının kek özellikleri üzerine olan etkisini incelemişlerdir. Keklere diyet lifi ilavesi ile örneklerin sertlik değerinde azalma olduğu ve diyet lifi içeren keklerin daha yumuşak olduğu belirtilmiştir. Ayrıca diyet lifi ilavesi kek örneklerinin hacmi ile sertlik değerlerini ters orantılı olarak etkilemiştir. Örneklerin içerdiği diyet lifi miktarının artmasıyla hacim değerlerinin arttığı ancak daha yumuşak 
yapıda kek elde edildiği görülmüştür. Gerçekleştirilen çalışmada da diyet lifi ilavesi ile glutensiz keklerin hacim değerleri artmakla birlikte daha yumuşak yapıda kek elde edilmektedir.

Örneklere ait esneklik değerleri 0.93-0.99 arasında değişim göstermekte olup, diyet lifi ile zenginleştirmenin örneklerin esneklik değerleri üzerine anlamlı bir etkisi olmadığı saptanmıştır $(P$ $>0.05)$. Örneklerin yapışkanlık değerleri 0.69-0.73 arasında, elastikiyet değerleri ise 0.31-0.34 arasında değişim göstermekte olup istatistiksel olarak anlamlı fark bulunmuştur $\left(\begin{array}{ll}P & <.05\end{array}\right)$. Gómez vd. (2011) farklı diyet lifi kullanımı ile üretilen kek örneklerinin yapışkanlık ve elastikiyet değerlerinde diyet lifi miktarının artmasıyla azalma olduğunu belirtmişlerdir.

\section{TARTIŞMA}

Farklı oranlarda diyet lifi ile zenginleştirilmiş glutensiz kek formülasyonları geliştirilerek, elde edilen hamurların doğrusal olmayan reolojik özellikleri LAOS yöntemi kullanılarak araştırlmıştır. Elde edilen sonuçlara göre diyet lifi ilavesi hamurların viskoelastik özelliklerini etkilemekte ve glutensiz kek örneklerinin kalitesini geliştirmektedir. Gerinimin bir fonksiyonu olarak elde edilen stres tepkileri öncelikle Lissajous eğrileri ile görsel olarak değerlendirilmiştir. Örneklerin doğrusal olmayan elastik ve viskoz davranışları farklı gerinim değerlerinde elde edilen stres tepkileri ile belirlenmiş ve Lissajous eğrilerinde meydana gelen sapmalardan hamurların doğrusal olmayan özellikleri gözlemlenmiştir.

Örneklerin doğrusal olmayan davranışının kantitatif olarak incelenmesi için örneklere ait Chebysev katsayilar1 $\left(e_{3} / e_{1}-v_{3} / v_{1}\right)$ değerlendirilmiştir. Diyet lifi miktarının artmasıyla Chebysev katsayılarının da artış gösterdiği görülmüştür. Örneklerin düşük gerinim değerlerinde doğrusal elastik ve viskoz özellik gösterdiği belirlenmiştir. Diyet lifi miktarının artması ile birlikte örneklere ait $e_{3} / e_{1}$ değerlerinin pozitif olduğu gerinim aralığ1 genişlemekte ve gerinim ile sertleşen özellik gösterdiği aralık artarken; gerinim ile yumuşama görülen aralıkta azalma olduğu saptanmıştur. Gerilim ile sertleşen davranışın örneğin kompleks yapısından ve proteinler ile nişasta moleküllerinin diyet lifi ile olan etkileşiminden kaynaklanabileceği düşünülmektedir. Tüm örneklerin $v_{3} / v_{1}$ değerleri, \%0-300 gerinim değerleri arasında sıfırdan küçük olduğu için kayma ile incelen özellik göstermiştir. Sonuç olarak, glutensiz kek hamurlarının diyet lifi ile zenginleştirilmesi doğrusal olmayan viskoelastik özellikleri büyük ölçüde etkilemektedir. LAOS analizi ile örneklerin yapısal farklılikları derinlemesine incelenebilmekte ve ürün kalitesinin geliştirilebilmesinde kullanılabilmektedir.

\section{TEŞEKKÜR}

$\mathrm{Bu}$ çalş̧ma Türkiye Bilimsel ve Teknolojik Araşturma Kurumu (TÜBİTAK) [Proje No: 215O227] ve Ege Üniversitesi Bilimsel Araştırma Projeleri Koordinatörlügü [Proje No: 15 MÜH 062] tarafindan desteklenmiştir.

\section{KAYNAKLAR}

AACC. (2000). Approved methods of the AACC, 10th ed., St. Paul, MN: AACC (Am Assoc Cereal Chem) Monogr, (Method 72-10).

Al-Sayed, H.M., Ahmed, A.R. (2013). Utilization of watermelon rinds and sharlyn melon peels as a natural source of dietary fiber and antioxidants in cake. Ann Agr Sci, 58(1), 83-95. https://doi.org/10.1016/j.aoas.2013.01.012.

AOAC Official Methods of Analysis. (1998). Method 991.43, total, soluble, and insoluble dietary fiber in foods. AOAC (Assoc Off Anal Chem Intern), Gaithersburg.

Arendt, E. K., O’Brien, C.M., Schober, T., Gormley, T.R., Gallagher E. (2002). Development of gluten-free cereal products. Farm Food, 12, 21-27. http://hdl.handle.net/ 10197/6892.

Bagley, E.B., Dintzis, F.R., Chakrabarti, S. (1998). Experimental and conceptual problems in the rheological characterization of wheat flour doughs. Rheol. Acta, 37, 556-565. https://doi.org/10.1007/s003970050142.

Bazzano, L. A., He, J., Ogden, L. G., Loria, C. M., Whelton, P. K. (2003). Dietary fibre intake and 
reduced risk of coronary heart disease in US men and women: the National Health and Nutrition Examination Survey I epidemiologic follow-up study. Arch Intern Med, 163, 1897-1904. https://doi:10.1001/archinte.163.16.1897.

Bonafaccia, G., Marocchini, M., Kreft, I. (2003). Composition and technological properties of the flour and bran from common and tartary buckwheat, Food Chem, 80: 9-15, https://doi.org/10.1016/S0308-8146(02)002285.

Choi I., Han O. K., Chun J., Kang C. S., Kim K. H., Kim Y. K., Kim K. J. (2012). Hydration and Pasting Properties of Oat (Avena sativa) Flour. Prev Nutr Food Sci, 17(1), 87. doi: 10.3746/pnf.2012.17.1.087.

de Moraes Crizel T, Jablonski A, de Oliveira Rios A, Rech R, Flôres SH. (2013). Dietary fiber from orange byproducts as a potential fat replacer. LWT-Food Sci Technol, 53(1):9-14, https://doi.org/10. 1016/j.lwt.2013.02.002.

Demirkesen, I., Mert, B., Sumnu, G., Sahin S. (2010). Rheological properties of gluten-free bread formulations, J Food Eng, 96: 295-303, https://doi.org/10.1016/j.jfoodeng.2009.08.004.

Duvarci O.C., Yazar G., Kokini J.L. (2017). The comparison of LAOS behavior of structured food materials (suspensions, emulsions and elastic networks). Trends Food Sci Tech, 60, 2-11. https://doi.org/10.1016/j.tifs.2016.08.014.

Faivre J., Bonithon-Kopp C. (1999). Diets, fibres and colon cancer. Adv Exp Med Biol, 472, 199206. https://doi.org/10.1007/978-1-4757-32306_17.

Fasano, A., Berti, I., Gerarduzzi, T., Not, T., Colletti, R. B., Drago, S., Pietzak, M. (2003). Prevalence of celiac disease in at-risk and not-atrisk groups in the United States: a large multicenter study. Arch Intern Med, 163(3), 286292, doi:10.1001/archinte.163.3.286.

Gelroth J., Ranhotra G. R. (2001). In S. S. Cho, M. L. Dreher (Eds.), Handbook of dietary fibre. New York: Marcel Dekker Inc.

Gómez M., Ronda F., Caba1llero P.A., Blanco C.A., Rosell C.M. (2007). Functionality of different hydrocolloids on the quality and shelflife of yellow layer cakes, Food Hydrocoll, 21, 167173. https://doi.org/10.1016/j.foodhyd.2006.03.012.

Gómez M., Ruiz E., Oliete B. (2011). Effect of batter freezing conditions and resting time on cake quality, LWT-Food Sci Technol, 44, 911-916. https://doi.org/10.1016/j.lwt.2010.11.037.

Grigelmo-Miguel N., Carreras-Boladeras E., Martin-Belloso O. (1999). Development of high fruit-dietary fiber muffins. Eur Food Res Technol, 210(2):123-128. s002170050547.

Gularte M. A.,de la Hera E., Gómez M., Rosell C. M. (2012). Effect of different fibers on batter and gluten-free layer cake properties. , LWT-Food Sci Tecbnol, 48, 209-214. https://doi.org/10.1016/j.lwt.2012.03.015.

Hyun K., Wilhelmb M., Kleinb C.O., Choc K.S., Namd J.G., Ahnd K.H., Leed S.J., Ewoldt R.H., McKinley G.H. (2011). A review of nonlinear oscillatory shear tests: Analysis and application of large amplitude oscillatory shear (LAOS). Prog Polym Sci, 36, 1697-1753. https://doi.org/ 10.1016/j.progpolymsci.2011.02.002.

Joyner H.S., Meldrum A. (2016). Rheological study of different mashed potato preparations using large amplitude oscillatory shear and confocal microscopy. J Food Eng, 169, 326-337. https://doi.org/10.1016/j.jfoodeng.2015.08.032.

Lario Y., Sendra E., Garc $\square$ J., Fuentes C., SayasBarberá E., Fernández-López J., Perez-Alvarez J.A. (2004). Preparation of high dietary fiber powder from lemon juice by-products. Innov Food Sci Emerg Technol, 5(1), 113-117. https://doi.org/10.1016/j.ifset.2003.08.001.

Larrauri JA. (1999). New approaches in the preparation of high dietary fibre powders from fruits by-products. Trends Food Sci Technol, 10(1):38. https://doi.org/10.1016/S0924-2244(99) 00016-3.

Lebesi D.M., Tzia C. (2011). Effect of the addition of different dietary fiber and edible cereal bran sources on the baking and sensory characteristics of cupcakes. Food Bioprocess Technol, 
4(5) 710-722. https://doi.org/10.1007/s11947009-0181-3.

Matos M. E., Sanz T., Rosell C.M. (2014). Establishing the function of proteins on rheological and quality properties of rice based gluten free muffins. Food Hydrocoll, 35, 150-158. https://doi.org/10.1016/j.foodhyd.2013.05.007.

Ng S.K., McKinley G.H., Ewoldt R.H. (2011). Large oscillatory shear flow of gluten dough: A model power-law gel. J of Rheol, 55, 627-654. https://doi.org/10.1122/1.3570340.

Osundahunsi O.F., Fagbemi T.N., Kesselman E., Shimoni E. (2003). Comparison of the physicochemical properties and pasting characteristics of flour and starch from red and white sweet potato cultivars. J Agr Food Chem, 51, 2232-2236. https://doi.org/10.1021/jf0260139.

Ptaszek P. (2015). A geometrical interpretation of large amplitude oscillatory shear (LAOS) in application to fresh food foams. J Food Eng, 146, 53-61. https://doi.org/10.1016/j.jfoodeng. 2014.08.022.

K.L. (1988). The physiological effects of dietary fiber-a review. Top Catal, 2(1), 1-18. https://doi.org/10.1016/S0268-005X(88)80033$\mathrm{X}$.

Sabanis D., Lebesi D., Tzia C. (2009). Effect of dietary fibre enrichment on selected properties of gluten-free bread. LWT - Food Sci Technol, 42, 1380-1389. https://doi.org/10.1016/j.lwt. 2009.03.010.

Shevkani K., Kaur A., Kumar S., Singh N. (2015). Cowpea protein isolates: Functional properties and application in gluten-free rice muffins. $L W T$ - Food Sci Technol, 63(2), 927-933. https://doi.org/10.1016/j.lwt.2015.04.058.

Sicherer S. H., Sampson H. A. (2014). Food allergy: epidemiology, pathogenesis, diagnosis, and treatment. J Allergy Clin Immunol, 133(2), 291307. https://doi.org/10.1016/j.jaci.2013.11.020.

Singh B., Sekhon K. S., Singh N. (1995). Suitability of full fat and defatted rice bran obtained from Indian rice for use in food products. Plant Foods Hum Nutr, 47(3), 191-200. https://doi.org/10.1007/BF01088327.

Steadman KJ, Burgoon MS, Lewis BA, Edwardson SE, Obendorf RL. (2001). Minerals, phytic acid, tannin and rutin in buckwheat seed milling fractions. J Sci Food Agric, 81:1094-1100. https://doi.org/10.1002/jsfa.914

Thebaudin J. Y., Lefebvre A. C., Harrington M., Bourgeois, C. M. (1997). Dietary fibres: nutritional and technological interest. Trends Food Sci Technol, 8, 41-49. https://doi.org/10.1016/ S0924-2244(97)01007-8.

Thompson T., Dennis M., Higgins L. A., Lee A. R., Sharrett M. K. (2005). Gluten- free diet survey: are Americans with celiac disease consuming recommended amounts of fibre, iron, calcium and grain foods. J Hum Nutr and Diet, 18, 163-169. https://doi.org/10.1111/j.1365-

277X.2005.00607.x.

Torbica, A., Hadnađev, M. and Hadnađev, T. D. (2012). Rice and buckwheat flour characterisation and its relation to cookie quality, Food Res Int, 48(1): 277-283, https://doi.org/10.1016/ j.foodres.2012.05.001.

Tsatsaragkou K., Papantoniou M., Mandala I. (2015). Rheological, Physical, and Sensory Attributes of Gluten-Free Rice Cakes Containing Resistant Starch, J Food Sci, 80(2), /doi.org/ 10.1111/1750-3841.12766.

Turabi, E., Sumnu, G., Sahin, S. (2008). Rheological properties and quality of rice cakes formulated with different gums and an emulsifier blend, Food Hydrocoll, 22, https://doi.org/ 10.1016/j.foodhyd.2006.11.016.

Yazar G., Duvarci O., Tavman S., Kokini, J. L. (2017). Non-linear rheological behavior of glutenfree flour doughs and correlations of LAOS parameters with gluten-free bread properties. $J$ Cereal Sci, 74, 28-36. https://doi.org/10.1016/ j.jcs.2017.01.008 